\title{
Modeling approaches to informatization of project activities in secondary school
}

\author{
Elena A. Miryugina $\mathbb{\circledR}^{\square}$, Viktor S. Kornilov \\ Moscow City University, \\ 29 Sheremetyevskaya St, Moscow, 127521, Russian Federation \\ $\checkmark$ miryugina.ea@yandex.ru
}

\begin{abstract}
Problem and goal. In the system of modern education, the issue of informatization of project activities is studied only in terms of its use within individual subject areas. This significantly narrows the possible effect of using this method at the intersection of subject areas, which was the original purpose of creating and describing this method. At the same time, it is extremely rare to mention the construction of a school project management system, although management is also necessary for the implementation of the project, especially when it comes to projects at the intersection of subject areas, when entire teams of project coordinators (subject teachers), teams of project participants (students), representatives from enterprises and/or universities (project partners) are involved. The purpose of our research is to model approaches to informatization of project activities. Methodology. Project management is sufficiently described in modern literature and research, and the standards of project management are described and accepted all over the world. In our study, to model approaches to informatization of project activities, we will rely on the experience of using the method in the economy and on the standards adopted worldwide and in the Russian Federation. Results. The conducted research has shown that in education it is possible to effectively apply the approaches that have proven themselves in the economy, which makes it possible to effectively apply the project method in educational activities. Conclusion. We were able to apply universal standards of project management to model approaches to informatization of project activities, which in the future will allow us to organize the project activities of schoolchildren at a fundamentally new level.
\end{abstract}

Keywords: informatization of education, project method, project management, project management system

Article history: received 15 January 2021; accepted 24 February 2021.

For citation: Miryugina EA, Kornilov VS. Modeling approaches to informatization of project activities in secondary school. RUDN Journal of Informatization in Education. 2021;18(2):128-136. http://dx.doi.org/10.22363/2312-8631-2021-18-2-128-136 


\title{
Моделирование подходов к информатизации проектной деятельности в средней школе
}

\author{
Е.А. Мирюгина $\mathbb{D}^{\otimes}$, В.С. Корнилов $\mathbb{D}$ \\ Московский городской педагогический университет, \\ Российская Федераџия, 127521, Москва, ул. Шереметьевская, д. 29 \\ $\square$ miryugina.ea@yandex.ru
}

\begin{abstract}
Аннотация. Проблема и цель. В системе современного образования вопрос информатизации проектной деятельности исследован лишь в части его использования в рамках отдельных предметных областей. Это значительно сужает возможный эффект от применения данного метода на стыке предметных областей, что являлось изначальной целью его создания. К тому же крайне редко упоминается построение системы управления школьными проектами, хотя для реализации проекта необходимо в том числе управление, особенно в проектах на стыке предметных областей, когда задействованы целые команды: координаторов проекта (учителя-предметники), его участников (ученики), представителей от предприятий и/или вузов (партнеры проекта). Таким образом, цель исследования - моделирование подходов к информатизации проектной деятельности. Методология. Проектный менеджмент достаточно описан в современной литературе и исследованиях, существуют соответствующие общепринятые стандарты. При моделировании подходов к информатизации проектной деятельности привлекался опыт использования метода в экономике, применялись мировые и российские стандарты. Результаты. Показано, что подходы, зарекомендовавшие себя в экономике, эффективны и в образовании, что позволяет использовать метод проектов в образовательной деятельности. Заключение. Применение универсальных стандартов проектного менеджмента для моделирования подходов к информатизации проектной деятельности в дальнейшем позволит организовывать проектную деятельность школьников на принципиально новом уровне.
\end{abstract}

Ключевые слова: информатизация образования, метод проектов, проектный менеджмент, система управления проектами

История статьи: поступила в редакцию 20 января 2021 г.; принята к публикации 24 февраля 2021 г.

Для цитирования: Miryugina E.A., Kornilov V.S. Modeling approaches to informatization of project activities in secondary school // Вестник Российского университета дружбы народов. Серия: Информатизация образования. 2021. Т. 18. № 2. С. 128-136. http://dx.doi.org/10.22363/2312-8631-2021-18-2-128-136

Problem statement. The project method has been actively used in modern pedagogy since the 20th century (see, for example, [1-3]). We live in the digital age, when activities can no longer exist outside of digital spaces, when it is impossible to neglect modern technologies. Long-established methods should be improved taking into account the use of modern technologies for their implementation. So the project method, which has long been used in education, as well as in the economy, is undergoing changes and gaining new opportunities. In business, this method has undergone a digital transformation, it is no longer used outside of 
digital technologies, since the method was able to be integrated into business management systems. In education, however, there is no such system informatization of the project method, which, in our opinion, does not allow us to use it fully.

Subprojects in school are often understood as abstract research on a specific topic, creating a presentation and presentation, and defending a project. The most accurate use of the project method can be traced in computer science, when children create a software product with its subsequent protection for the audience. And in business, the method has found the greatest application in IT companies.

Currently, there are enough software products that allow you to manage projects. But considering the research in the field of application of the project method and its informatization, we noticed that in pedagogy, the project method is considered from the point of view of creating a project and an important part is missed project management. Of course, when applying the project method in education, we are talking about two sides: the didactic part and the educational project itself. As part of the research hypothesis, we assume that we will be able to apply the experience and standards of applying the project method in business, project management technology in business for the implementation of educational projects.

Another task that becomes most effectively solved when using the project method using information technology is the task of evaluating the work of students, especially relevant, evaluating each team member while working on the project. For teachers, the important task of accumulating grades in the subjects taught is solved. Since one of the difficulties of implementing project activities in the educational process is also the formation of a balanced load of the student and teacher, since there are already working programs in the subjects, there is a schedule: the time of students and teachers is scheduled. And there is always the question of how to organize the work on the project. Of course, in high school there is a separate time allocated for the subject "individual project", but we understand that this is not enough for the full implementation of the project, as well as the participation of only one teacher to work with students on an interdisciplinary project. In other words, project activities should be integrated into the quality management system of the educational organization, and not be something foreign, additional, complicating the work of students and teachers.

Method of research. The study used a modeling method, and also analyzed the national standards of the Russian Federation on project management ${ }^{1}$ for modeling the educational project management system using information technologies.

${ }^{1}$ GOST R 54869-2011. Project management. Requirements for project management (approved and put into effect by the Order of Rosstandart of 22.12.2011 No 1582-st). Moscow: Standartinform Publ.; 2012; GOST R 56715.1-2015. Project management. Project management systems. Part 1. Basic provisions (approved and put into effect by the Order of Rosstandart of 17.11.2015 No 1824-st). Moscow: Standartinform Publ.; 2017; GOST R 56715.2-2015. Project management. Project management systems. Part 2. Processes and the process model (approved and put into effect by the Order of Rosstandart of 17.11.2015 No 1825-st). Moscow: Standartinform Publ.; 2016; GOST R 56715.3-2015. Project management. Project management systems. Part 3. Methods (approved and put into effect by the Order of Rosstandart of 17.11.2015 No 1826-st). Moscow: Standartinform Publ.; 2016; GOST R 56715.4-2015. Project management. Project management systems. Part 4. Data and data model (approved and put into effect by the Order of Rosstandart of 17.11.2015 No 1827-st). Moscow: Standartinform Publ.; 2016; GOST R 56715.5-2015. Project 
Results and discussions. The Federal State Educational Standard for Secondary General Education provides for the implementation of an individual project by students for a year or two years, while projects are classified as information, creative, applied, design, engineering, and so on $^{2}$. For such a long-term work, a well-developed project management system is necessary, which also includes a control system.

For these purposes, we have built a model of educational project management, based on the national standards of the Russian Federation on project management.

To build a system of processes, we take as a basis the system adopted in one of the national standards of the Russian Federation ${ }^{3}$, and project it on the management of the school project (Figure 1).

The standards define five consecutive phases of the project life cycle, which are shown in Figure 2.

\begin{tabular}{|c|c|}
\hline \multicolumn{1}{|c|}{ Process system } & The system of processes in the school \\
\hline $\begin{array}{c}\text { Project management } \\
\text { processes } \\
\text { Project management } \\
\text { processes }\end{array}$ & $\begin{array}{c}\text { A team of teachers who are involved in the } \\
\text { project supervision } \\
\text { main topic of the project, or a representative of the } \\
\text { school administration) }\end{array}$ \\
\hline Supporting processes & $\begin{array}{c}\text { Team members are projects that deal with financial } \\
\text { calculations, providing the team with materials, and } \\
\text { searching for resources }\end{array}$ \\
\hline Product creation processes & $\begin{array}{c}\text { Team members who are engaged in direct work on the } \\
\text { product, including marketing, design, etc }\end{array}$ \\
\hline
\end{tabular}

Figure 1. Project management process system

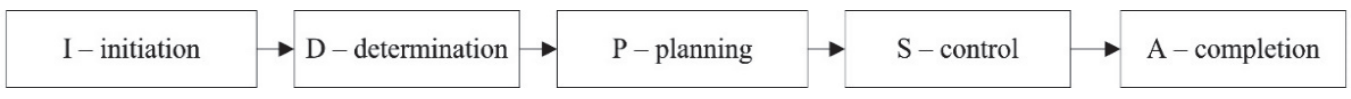

Figure 2. Project life cycle

Moreover, the subsequent phase cannot begin without the successful completion of the previous phase. This is the key to the quality of project management.

management. Project management systems. Part 5. Terms and definitions (approved and put into effect by the Order of Rosstandart of 17.11.2015 No 1828-st). Moscow: Standartinform Publ.; 2017.

${ }^{2}$ Order of the Ministry of Education and Science of the Russian Federation of 17.05.2012 No 413 "On approval of the Federal State Educational Standard of Secondary General Education" (registered with the Ministry of Justice of the Russian Federation on 07.06.2012 No 24480). Rossiyskaya Gazeta. 21 June 2012. No 139.

${ }^{3}$ GOST R 56715.2-2015. Project management. Project management systems. Part 2. Processes and the process model (approved and put into effect by the Order of Rosstandart of 17.11.2015 No 1825-st). Moscow: Standartinform Publ.; 2016. 
At the first stage of the project life cycle (initiation), work is carried out on the formation of the project team, the distribution of roles in the team, and the definition of project goals. At the same time, it is important to note that when determining the project goals, the team needs to answer the following questions: what task is being solved? Who is the beneficiary as a result of solving the problem? What concrete and measurable benefits does it acquire?

At the second stage (definition), the team determines the list of the main interim results of the project, the list of necessary resources for the implementation of the project. Moreover, the project manager helps teams identify the main interim results, determine the order and forms of reporting on each result, taking into account the roles of each team member (you can say, determine the list of tasks for team members). Also, the project management team, together with the project team members, determines the criteria and indicators of the quality of the results obtained (used for evaluating the subjects in which the competencies necessary for the implementation of the project were obtained).

During the planning phase, the interim results of the project receive specific deadlines - a project implementation plan and a reporting plan are formed. It also defines the methods of working with changes - the procedure for making changes to the project implementation plan.

After the planning is fully completed, the monitoring phase begins: students' activities to implement the plan are launched, taking into account all planned reporting. At the same time, the project curators (project management) - subject teachers - evaluate the implementation of the corresponding intermediate results. The final process of this phase is the acceptance of the project.

At the completion phase, a final report on the project is prepared, an archive of project documentation is formed, achievements are evaluated, and project experience is summarized.

The experience of using information technologies in schools shows that despite the wide variety of technologies and their huge capabilities, it is not always easy for teachers to understand in what situation and how to use these technologies [4]. In our research, we help to solve this problem by showing the possibility of using specific technologies in this situation, namely in the processes of managing educational projects.

In order to be able to effectively implement the management of all phases of the project, we used the Trello project management system. The most important thing, in our opinion, is that this system allows all project participants to communicate with each other, record all comments and discussion stories, exchange external files within the project, and each file will be linked to a specific point in the project implementation plan and will be stored directly in the information system, which will allow all project participants to have access to information regardless of their location.

For automation purposes, we have created two electronic boards "Project preparation" and "Project implementation". Moreover, the "Project preparation" board is a standard one, suitable for any project (Figures 3, 4).

The electronic board "Project implementation" will already be individual for each project and will be built in accordance with the plan. Moreover, for each element of the plan, you can assign those responsible and describe the task and the reporting procedure in more detail in the card, set deadlines, and the system will auto- 
matically remind you of the deadline for a particular task. It is important that each element of the plan can be broken down into smaller steps, the so-called checklist. The system also allows project participants to comment on the progress of the project for each step (inside the card).

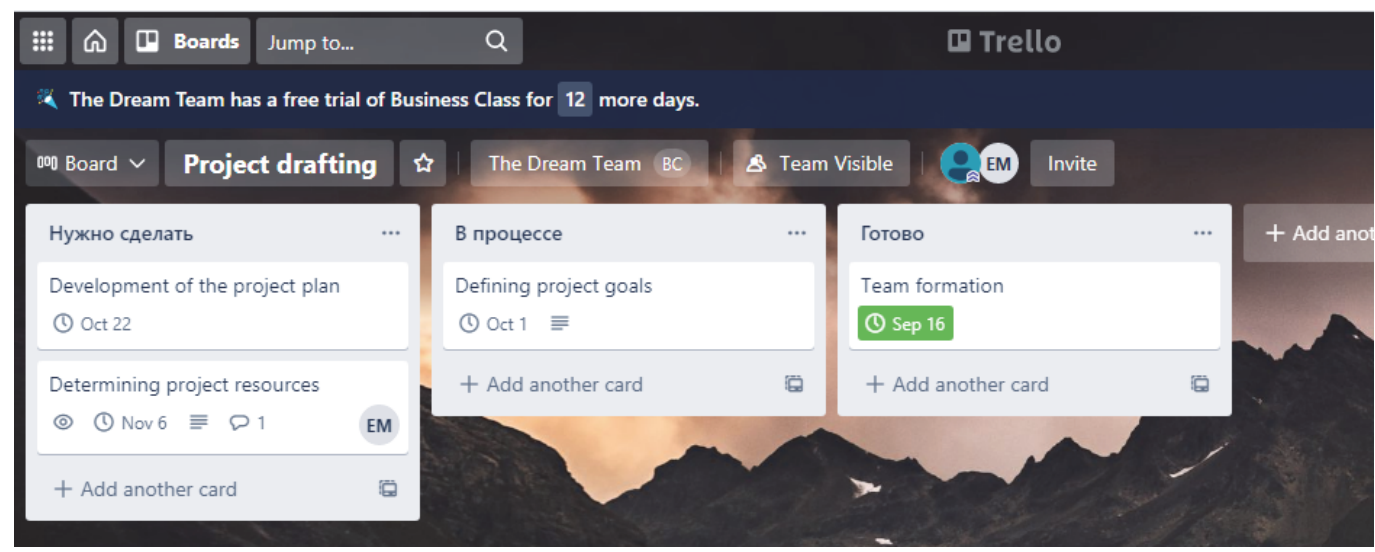

Figure 3. Electronic board "Project preparation"

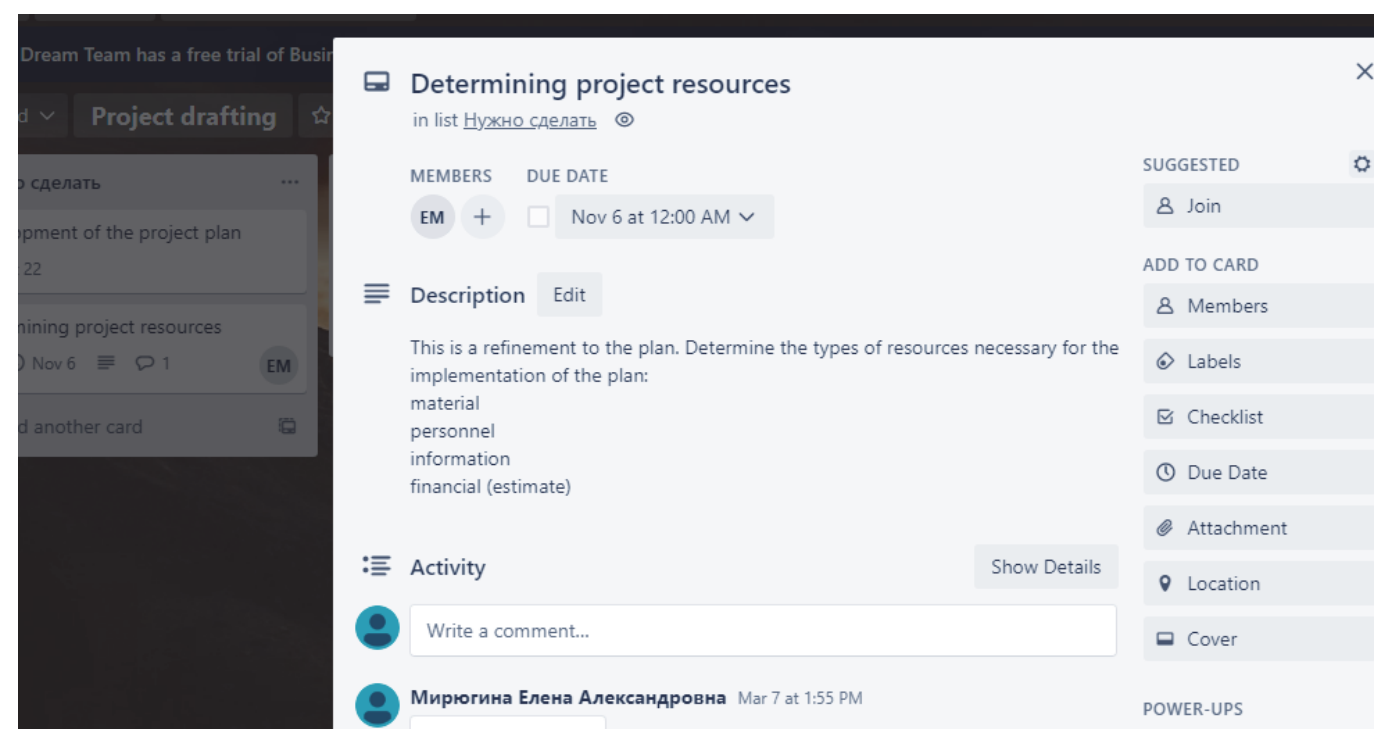

Figure 4. Electronic board "Project implementation"

Teachers-curators, along with curators from universities or enterprises, should also have access to the boards to directly comment, answer questions, and evaluate the progress of the project.

We get a network structure that allows many project participants to interact within the framework of working on the project at once. These technologies are close and understandable to modern schoolchildren, they are one of the trends of the digital age, which makes it possible to further interest children [5].

But there are also disadvantages to this system. This is an external system for the school, it requires additional authorization of users, individual accounts. Trello can be added to the classroom in the Teams system from Microsoft Office, which was actively used in the distance learning format during the restrictive 
measures related to the pandemic, but these systems are not directly integrated with the Moscow e-School.

Of course, if there are grounds for using the project method at the level of the Federal State Educational Standard, it is necessary to study the issue of providing students with the opportunity to manage projects using the platform of the Moscow e-School. This approach would allow us to apply scientifically proven requirements for standardization and unification of educational resources [6], which would raise the level of informatization to a higher level. Thus, it would be easier to methodically describe the project, immediately assigning to each stage of the project the necessary elements of the curriculum of the relevant subject, and then evaluate the project not only as a whole, but to transfer the assessments to the relevant subject topics with automatic grading in an electronic journal, thereby using the project activity not as something separate, but as a component of the educational process, a component of the educational program, work at the intersection of subject areas.

Conclusion. For the full and modern use of the project method in the digital age, it is most effective to use modern technologies [7; 8]. Our main conclusions are that when using the project method in educational activities, it is also important to pay attention to building a project management system, as if we were working on projects in professional activities. Moreover, the use of network technologies plays an important role in the informatization of educational project management, that is, project management systems contain all the functions of network interaction and cloud technologies. Moreover, the use of the project method in educational activities with the use of project management information systems introduces students not only to work in projects, to work in teams, but also to use modern technologies, which allows high school students to gain competencies in the field of modern technologies that are used in real professional activities [7; 9-15].

Thus, we believe that it is necessary to use project management information systems for educational projects in high school, and we were able to successfully use the experience of project management in professional activities in the management of educational projects in high school.

\section{References}

[1] Miryugina EA. Method of projects-effective pedagogical technology of teaching schoolchildren. Bulletin of the Moscow City Pedagogical University. Series: Informatics and Informatization of Education. 2020;3(53):75-83. (In Russ.)

[2] Miryugina EA. Informatization as a means of project activity management in education. Bulletin of the Moscow City Pedagogical University. Series: Informatics and Informatization of Education. 2020;4(54):51-59. (In Russ.)

[3] Zaslavskaya OY, Simonyan AV. Designing a learning management system based on the project management method. RUDN Journal of Informatization in Education. 2020; 17(2):107-122. (In Russ.)

[4] Grinshkun VV. The need for remote learning - an incentive for the formation and development of the digital environment of an educational organization. Bulletin of the Moscow City Pedagogical University. Series: Informatics and Informatization of Education. 2020;2(52):8-15. (In Russ.)

[5] Kondakov AM. Education in the era of the fourth industrial revolution. Vesti Obrazovaniya. 2017;(9). (In Russ.) Available from: http://edition.vogazeta.ru/ivo/info/14963.html (accessed: 15.02.2021). 
[6] Grinshkun VV. Development of integrative approaches to the creation of educational informatization tools (dissertation of the Doctor of Pedagogical Sciences). Moscow; 2004. (In Russ.)

[7] Prohorov A, Konik L. Digital transformation. Analysis, trends, world experience. Moscow: Al'yansPrint; 2019. (In Russ.)

[8] Sulejmanov RS, Bulin-Sokolova EI, Vardanyan VA, Eroshkina OA, Dronov MA. Analysis of the possibility of implementing assessment methods and receiving feedback using learning management systems. Bulletin of the Moscow City Pedagogical University. Series: Informatics and Informatization of Education. 2020;4(54):60-67. (In Russ.)

[9] Babinova NV. Formation of readiness for the development of universal educational actions in older preschool children in project activities (dissertation of the Candidate of Pedagogical Sciences). Ekaterinburg; 2018. (In Russ.)

[10] Belokopytova SV. Formation of teenagers' readiness for health care by means of project activity (dissertation of the Candidate of Pedagogical Sciences). Lipetsk; 2019. (In Russ.)

[11] Oparina EV. Development of social skills of schoolchildren in extracurricular project activities in different age groups (dissertation of the Candidate of Pedagogical Sciences). Moscow; 2019. (In Russ.)

[12] Pastuhova LS. Socio-project activity as a space for the development of civil identity of youth (dissertation of the Candidate of Pedagogical Sciences). Moscow; 2019. (In Russ.)

[13] Khacharoeva AH. Formation of civil-legal competence of schoolchildren in project activity (dissertation of the Candidate of Pedagogical Sciences). Makhachkala; 2020. (In Russ.)

[14] Chudinova AR. Development of the communicative competence of primary school students by means of project activity (on the example of studying the scientific style of speech) (dissertation of the Candidate of Pedagogical Sciences). Perm; 2018. (In Russ.)

[15] Shigapova NV. Project technology of formation of cognitive universal educational actions of younger schoolchildren in the process of teaching the course "The surrounding world" (dissertation of the Candidate of Pedagogical Sciences). Kazan; 2014. (In Russ.)

\section{Список литературы}

[1] Мирюгина E.A. Метод проектов - эффективная педагогическая технология обучения школьников // Вестник Московского городского педагогического университета. Серия: Информатика и информатизация образования. 2020. № 3 (53). С. 75-83.

[2] Мирюгина E.A. Информатизация как средство управления проектной деятельностью в образовании // Вестник Московского городского педагогического университета. Серия: Информатика и информатизация образования. 2020. № 4 (54). С. 51-59.

[3] Заславская O.Ю., Симонян А.В. Проектирование системы управления обучением на основе метода управления проектами // Вестник Российского университета дружбы народов. Серия: Информатизация образования. 2020. Т. 17. № 2. С. 107-122.

[4] Гриншкун B.B. Необходимость удаленного обучения - стимул для формирования и развития цифровой среды образовательной организации // Вестник Московского городского педагогического университета. Серия: Информатика и информатизация образования. 2020. № 2 (52). С. 8-15.

[5] Кондаков A.M. Образование в эпоху четвертой промышленной революции // Beсти образования. 2017. № 9. URL: http://edition.vogazeta.ru/ivo/info/14963.html (дата обращения: 15.02.2021).

[6] Гриншкун B.B. Развитие интегративных подходов к созданию средств информатизации образования: дис. ... д-ра пед. наук. М., 2004. 554 с.

[7] Прохоров А., Коник Л. Цифровая трансформация. Анализ, тренды, мировой опыт. М.: АльянсПринт, 2019. 368 с.

[8] Сулейманов Р.С., Булин-Соколова Е.И., Варданян В.А., Ерошкина О.А., Дронов М.А. Анализ возможности реализации методов оценивания и получения обратной связи с помощью систем управления обучением // Вестник Московского городского 
педагогического университета. Серия: Информатика и информатизация образования. 2020. № 4 (54). С. 60-67.

[9] Бабинова Н.В. Формирование готовности к освоению универсальных учебных действий у детей старшего дошкольного возраста в проектной деятельности: дис. ... канд. пед. наук. Екатеринбург, 2018. 193 с.

[10] Белокопьтова С.В. Формирование готовности подростков к здоровьесбережению средствами проектной деятельности: дис. ... канд. пед. наук. Липецк, 2019. 195 с.

[11] Опарина E.B. Развитие социальных навыков школьников во внеурочной проектной деятельности в разновозрастных группах: дис. ... канд. пед. наук. М., 2019. $200 \mathrm{c}$.

[12] Пастухова Л.С. Социально-проектная деятельность как пространство развития гражданской идентичности молодежи: дис. ... канд. пед. наук. М., 2019. 398 с.

[13] Хачароева А.X. Формирование гражданско-правовой компетентности школьников в проектной деятельности: дис. ... канд. пед. наук. Махачкала, 2020. 175 с.

[14] Чудинова A.P. Развитие коммуникативной компетенции учащихся основной школы средствами проектной деятельности (на примере изучения научного стиля речи): дис. ... канд. пед. наук. Пермь, 2018. 340 с.

[15] Шигапова Н.В. Проектная технология формирования познавательных универсальных учебных действий младших школьников в процессе обучения курсу «Окружающий мир»: дис. ... канд. пед. наук. Казань, 2014. 276 с.

\section{Bio notes:}

Elena A. Miryugina, graduate student, Department of Education Informatization, Moscow City University. ORCID iD: http://orcid.org/0000-0001-5435-9199. E-mail: miryugina.ea@, yandex.ru

Viktor S. Kornilov, Doctor of Pedagogical Sciences, Candidate of Physical and Mathematical Sciences, Full Professor, Professor, Department of Education Informatization, Moscow City University. ORCID iD: http://orcid.org/0000-0003-0476-3921. E-mail: vs_kornilov@mail.ru

\section{Сведения об авторах:}

Мирюгина Елена Александровна, аспирант, департамент информатизации образования, Московский городской педагогический университет. ORCID iD: http://orcid.org/00000001-5435-9199. E-mail: ovchic@gmail.com

Корнилов Виктор Семенович, доктор педагогических наук, кандидат физико-математических наук, профессор, департамент информатизации образования, Московский городской педагогический университет. ORCID iD: http://orcid.org/0000-00030476-3921.E-mail: vs_kornilov@mail.ru 